\section{THE CCCTB INITIATIVE AS A POSSIBLE SOLUTION TO THE CONFLICT BETWEEN THE INTERNAL MARKET AND NATIONAL TAX AUTONOMY}

Juho Mäki-Lohiluoma'

Helsinki Law Review, 1/2019, pp. 150-179

(c) 2019 Pykälä ry, Mannerheimintie 3 B, 5th floor, 00100 Helsinki, Finland, and the author.

\section{VERTAISARVIOITU
KoLLEGALT GRANSKAD
PEER-REVIEWED
www.tsv.fittunnus}

Keywords:

The CCCTB Initiative, EU tax law, elimination of tax obstacles, regulatory frmaework

\section{ABSTRACT}

In 2016, the European Commission re-launched the project for a common consolidated corporate tax base with a two-step approach of two interconnected proposals of Common Corporate Tax Base (CCTB) and Common Consolidated Corporate Tax Base (CCCTB). The proposals faced fierce opposition from several Member States, even if few oppose combatting tax avoidance and eliminating tax obstacles of cross-border trade in principle.

This article examines the CССТВ proposal as a possible solution to the conflict between the internal market and national tax autonomy. When focusing strictly on the said proposals in their current form, analysis of their capabilities to solve the conflict seem dim. On the other hand, if the $\mathrm{CC}(\mathrm{C}) \mathrm{TB}$ is seen as a system of formula apportionment and as an evolving framework, which can be enacted in parts of the internal market through for example enhanced cooperation, the outcast looks more positive.

\section{INTRODUCTION}

The discussion of harmonizing corporate tax bases in the European internal market has been long-running. The first proposal of the Common Consolidated Corporate Tax Base (CCCTB) was submitted by the European Commission in 2011 and circulated in the political discussion until 2016, but failed to reach unanimity in the Council. ${ }^{2}$ In 2016, building on the 2011 proposal and the comments it received from the Council, the Commission re-launched the project for a common consolidated corporate tax base with a two-step approach of two interconnected proposals of Common Corporate Tax Base (CCTB) and CCCTB. ${ }^{3}$ Simultaneously, the previous CCCTB proposal was withdrawn.

The Commission's proposals on CCTB and CCCTB are part of a larger corporate tax reform package, also consisting of a double taxation dispute resolution mechanism and an extension of rules against hybrid mismatches. ${ }^{4}$

CCCTB and CCTB proposals are not the first try of the Commission to address the incompatibility of non-harmonized corporate tax systems and the internal market. The Commission has highlighted the importance of the issue for many years, starting with reports dating back to 1962,1970 and $1992 .^{5}$

When re-launching the initiative, the Commission stated that the previous proposal of 2011 had resulted in considerable progress on many of the core elements of CCCTB and Commission hoped for a quick agreement on CCTB, and the introduction of CCCTB soon afterwards. ${ }^{6}$ These hopes have proved ill-founded, since much of the criticism directed towards the 2011 proposal has been re-introduced in conjunction with the new proposals, and new concerns have even been raised concerning the Commissions two-step approach.

In principle, few oppose combatting tax avoidance and eliminating tax obstacles of crossborder trade. In opinion polls, EU citizens express strong support for EU involvement in the

2 European Parliamentary Research Service Briefing, "Common consolidated corporate tax base (CCCTB)", (PE 599.395, 2017), p. 1; European Commission, 'Proposal for a Council Directive on a Common Consolidated Corporate Tax Base (CCCTB)' COM (2011) O121 final.

3 European Council presidency compromise text on the Proposal on a Common Consolidated Corporate Tax Base (CCCTB), (2014) 15756/14, European Commission., 'Proposal for a Council Directive on a Common Corporate Tax Base (CCTB)' COM (2016) 685 final; European Commission, 'Proposal for a Common Corporate Tax Base (CCTB)' COM (2016) 685 final; European Commission, 'Proposal for a
Council Directive on a Common Consolidated Corporate Tax Base (CCCTB)' COM (2016) 683 final.

4 European Parliamentary Research Service Briefing, "Common consolidated corporate tax base European Parliamentary Research
(CCCTB)", (PE 599.395, 2017), p. 1.

5 European Commission, "Commission Staff Working Document: Corporate Income Taxation in the European Union", (SWD 121 final, 2015), p. 5.

1 Juho Mäki-Lohiluoma (LL.B., LL.M., University of Turku) is a Special Adviser to the Minister of Education of Finland. This article is based on his Bachelor's Thesis.
6 European Commission Press release, "Commission proposes major corporate tax reform for the EU", $(\mathrm{IP} / 16 / 3471,2016)$. 
fight against tax fraud and aggressive tax avoidance. ${ }^{7}$ This creates a gap between citizens' expectations and the depth of EU involvement: while citizens expect action from the European Union, the framework of European law on taxation issues creates multiple preconditions that are hard to achieve. Among them are unanimity in the Council and compliance with the principle of subsidiarity.

To national politicians, handing out parts of tax autonomy is challenging. This is best illustrated by the scope of powers that have been granted to the European legislature during the over 60 year existence of the project of European integration. Although the harmonization of taxation in the internal market has been more advanced in the case of indirect taxation, which dates back to the 1960's, matters of direct taxation have remained closely linked to Member State sovereignty, protected by the unanimity requirement and special legislative procedure. ${ }^{\mathbf{8}}$

The Commission's CCTB and CCCTB proposals can be viewed as means of fulfilling the gap between the current EU-level actions in combatting tax avoidance and citizens' expectations for EU involvement. They're first and foremost tax directives, although they operate on a legal basis linked to the functioning of the internal market.

The aim of this article is to examine the CCCTB proposal as a possible solution to the conflict between the internal market and national tax autonomy. In the article, provisions of the Directive proposal are observed and consequently contextualized in the EU law framework in which they either succeed or fail. The main research question is therefore: does the CCCTB initiative carry the necessary legal basis, quality and support for it to present a solution to the conflict between the internal market and national tax autonomy?

\section{CCCTB PROPOSAL AND FORMULA APPORTIONMENT IN THE FRAMEWORK OF EUROPEAN UNION LAW}

The proposed CCTB and CCCTB Directives fall under the scope of Article 115 of the Treaty on the Functioning of the European Union (TFEU). According to the Article, the Council shall act unanimously in accordance with a special legislative procedure to issue directives for the approximation of such laws, regulations or administrative provisions of the Member States that directly affect the establishment or functioning of the internal market. Therefore, tax harmonization can be executed through directives only, not regulations.

7 European Parliamentary Research Service Compendium of briefings, "Public opinion and EU policies - Exploring the expectations gap", (PE 586.596, 2016), p. 19-20

8 European Parliamentary Research Service, "Tax policy in the EU", (PE 586.596, 2016), p. 4-6.
Article 289(2) of the TFEU regulates the special legislative procedure that needs to be followed in the case of CСTB and СССТВ. In the special legislative procedure, the consultation but not consent of the European Parliament is required. The Council is, in effect, the sole legislator of CCTB and CCCTB.

Article 5(1) of the Treaty on European Union (TEU) states that the limits of Union competences are governed by the principle of conferral. The use of Union competences is governed by the principles of subsidiarity and proportionality.

Article 5 TEU further states that under the principle of subsidiarity, in areas which do not fall within its exclusive competence, the Union shall act only if and in so far as the objectives of the proposed action cannot be sufficiently achieved by the Member States but can be better achieved at Union level. Under the principle of proportionality, the content and form of Union action shall not exceed what is necessary to achieve the objectives of the Treaties.

Under the Protocol on the application of the principles of subsidiarity and proportionality, the so-called yellow card protocol, national parliaments have the right to give a reasoned opinion to the Commission when they consider that legislation proposed by the Commission does not comply with the principle of subsidiarity. ${ }^{9}$ According to the Protocol, if reasoned opinions are given by at least one third or the national parliaments, the draft must be reviewed. ${ }^{10}$

In the case of CСTB and CCCTB, seven reasoned opinions have been submitted by legislatures of six countries. ${ }^{11}$ The amount is not sufficient for the Commission to have an obligation to revisit the proposal, but significant when considering that unanimity in the Council is required for the proposal to pass into law.

The position of CCCTB Directive proposal in the framework of European Union law is challenging. By submitting the proposal, the Commission has relied on the legal basis of Article 115 TFEU. This is viewed by some as an overreach of powers and the Commission has received criticism on the compliance of the proposal with the fundamental principles of European union law.

The underlying objective of the CCTB and CCCTB proposals is to replace the current European corporate tax system, which is based on the idea of separate accounting, with the system of formula apportionment. The formula apportionment system itself is not an invention of the

9 Protocol (No 2) on the application of the principles of subsidiarity and proportionality [2016] OJ $\mathrm{C} 2 \mathrm{O} 2 / 206$, art 6 .

10 Ibid.

11 The Platform for EU Interparliamentary Exchange (IPEX), Proposal for a Council Directive on a Common Corporate Tax Base COM/2016/0685; The platform for EU Interparliamentary Exchange (IPEX) Proposal for a Council Directive on a Common Consolidated Corporate Tax Base COM/2016/0683 
European Commission. It is already used e.g. in allocating corporate income tax on the state level in the United States of America, on the province level in Canada, and on the cantonal level in Switzerland. ${ }^{\mathbf{2}}$ In Germany, it is applied in the distribution of the local business tax between municipalities. ${ }^{13}$

Under the current separate accounting system, companies calculate their income separately for entities operating under different tax jurisdictions, which in the case of the internal market mean Member States. For the purposes of calculating taxable income, corporate entities are required to apply market-based prices on internal transactions with their related entities located in different tax jurisdictions. In the separate accounting system, transactions between related parties are therefore treated as if they had occurred with independent entities. ${ }^{\mathbf{1 4}}$

Under the proposed formula apportionment system, a corporate group first calculates its net income for the entire group and then apportions that income to each location where it does business by using a specific formula. This formula can have multiple and diverse factors that together form the rules by which tax income is distributed. ${ }^{15}$

In general, the formula apportionment system does not necessarily attempt to identify the geographic source of a company's profits with unrivalled accuracy, but rather provides a rough approximation of the amount of income generated from the company's activity in each Member State. ${ }^{16}$ The method proposed by the Commission for apportionment is based on a threefactor formula. It is inspired by the Massachusetts formula, used by nine states in the USA, incorporating factors based on labour, property and sales in their equal weight. ${ }^{17}$

The formula apportionment system is not the only system that could be used for distributing the income from corporate taxes to Member States. The Commission has previously also explored home state taxation, in which companies would have the option of computing their income from operations in the whole internal market according to the tax rules of the Member State where their headquarters are located. ${ }^{18}$ One option has been the European Union company income tax, which would operate in parallel with existing national rules, and even a single EU tax base

12 Krchnivá, K., "The CCCTB Allocation Formula Game: The Performance of Economics Sectors." Prague Economic Papers, 2018, p. 2.

13 Ibid, p. 2 .

14 Gerard, M., Weiner, J. M., "Cross-Border Loss Offset and Formulary Apportionment: How Do They Affect Multijurisdictional Firm Investment Spending and Interjurisdictional Tax Competition?" CESifo. Working Paper No. 1004., p. 7.

15 Ibid, p. 7 .

16 Ibid, p. 7.

17 Krchnivá, K.," The CCCTB Allocation Formula Game: The Performance of Economics Sectors." Prague Economic Papers, 2018, p. 4.

18 Gerard, M., Weiner, J. M., "Cross-Border Loss Offset and Formulary Apportionment: How Do They Affect Multijurisdictional Firm Investment Spending and Interjurisdictional Tax Competition?" CESifo. Working Paper No. 1004., p. 6 and tax tode, which would replace national corporate tax systems. ${ }^{19}$ One possible solution would also be to proceed with non-binding agreements, instead of binding legal rules and a common legislative framework. The Commission views this approach as risky, because it might create legal uncertainty for taxpayers and jeopardize the objective of a coordinated and coherent corporate tax system in the internal market. ${ }^{20}$

Considering the EU law framework and legal basis for CCTB and CCCTB, it's obvious that some of the alternative solutions would face even greater criticism regarding their possible incompatibility with the principle of subsidiarity. Especially the introduction of a single EU tax base and tax code would be hard to justify. With the European citizens wishing for more actions by the EU in combatting tax avoidance, national governments and parliaments wanting to maintain their tax autonomy, and the Treaties providing little powers to regulate corporate taxation in the internal market, the Commission is stuck between contradictory pressures and walking a very thin line between overstepping its legislative powers and failing to address the issue of tax avoidance, which by many is deemed both unfair and unsustainable. Under these pressures, the Commission's selected method has been to build its legislative proposal on the system of formula apportionment, which in comparison with other possible solutions can be viewed as a method less restrictive of the tax autonomy of the Member States. The method in turn has been faced with some criticism on its limited abilities in combatting tax avoidance and fulfilling the Commission's aim of creating a level playing field in the internal market. ${ }^{21}$

\section{THE AIM OF THE COMMISSION}

It's a long-running claim of the Commission that a healthy internal market needs a fair, efficient and growth-friendly corporate tax system, based on the principle that companies should pay taxes in the country where profits are generated. ${ }^{\mathbf{2 2}}$ With CCCTB, the aim is to subject taxpayers to a single rulebook of corporate tax legislation which applies across the internal market and to make the system more robust and resilient to aggressive tax planning. According to the Commission, both objectives impact the internal market decisively and directly. ${ }^{\mathbf{2 3}}$

9 Ibid, p. 6

20 European Commission, 'Proposal for a Council Directive on a Common Consolidated Corporate Tax Base (CCCTB)' COM (2016) 683 final.

21 Bhogal, S., Swanson, K. "EU CCCTB: The Potential Successes and challenges" (International Tax Review, 2016).

22 Communication from the European Commission to the European Parliament and the Council, "Anti-Tax Avoidance Package: Next steps towards delivering effective taxation and greater tax transparency in the EU", (COM 23 final, 2016).

23 European Commission, 'Proposal for a Council Directive on a Common Consolidated Corporate Tax Base (CCCTB)' COM (2016) 683 final, Explanatory Memorandum. 
In its Working Document discussing corporate income taxation in the European Union, the Commission outlines the problematic development that the CCTB and CCCTB Directives are meant to tackle: more and more evidence suggests that considerable amounts of corporate income from cross-border activities can avoid taxation. ${ }^{24}$ Due to the ever-increasing complexity of business models and intra-group transactions, it is also increasingly difficult to determine where profits are generated and where they should be taxed.

The Working Document also illustrates that not only nominal tax rates are driving profit shifting, but also effective tax rates and possible loopholes that the differences in national tax rules create. ${ }^{\mathbf{2 5}}$ Therefore harmonization of corporate taxes doesn't necessarily have to mean harmonizing tax rates in the internal market, but rather harmonizing the way taxable profits are calculated and how cross-border intra-group transactions are treated.

According to the Commission, insufficient regulation on corporate taxation creates severe harm to the functioning of the internal market. Tax avoidance and aggressive tax planning distorts price signals and the allocation of resources and creates an uneven playing field for different types of companies. This is especially true when comparing small and medium sized enterprises that tend to face a higher tax-burden for following the tax regulation of an individual Member State with multinational companies with means and capabilities to benefit from incompatible corporate tax rules in the Member States. ${ }^{\mathbf{2 6}}$

In its Working Document, the Commission outlines the need for a European approach in tackling the issue. It states that while introducing unilateral anti-abuse measures by Member States might be a valuable short-term solution to fix the most pressing issues, the EU must make sure that an increase in national anti-abuse measures does not hamper the overarching goals of the single market, the creation of a capital markets union and the overall attractiveness of Europe at the global level. ${ }^{27}$

\section{PROVISIONS OF THE PROPOSED DIRECTIVES}

The proposals for ССТВ and СССТВ Directives are relatively complex legislative drafts with numerous technical details. Below, the more significant aspects of the proposed legislation are observed.

The CCCTB proposal for instance opts for a so-called one-stop shop solution when it comes to tax administrations and the division of tasks between them. Groups following the CCCTB

24 European Commission, "Commission Staff Working Document: Corporate Income Taxation in the European Union”, (SWD 121 final, 2015), p. 3.

25 Ibid, p. 3 .

26 Ibid, p. 4.

27 Ibid, p. 4 rules will deal with one tax administration in the EU (Principal Tax Authority), which is usually the Member State where the group's parent company is resident, which then in turn divides the tax income of the group between the Member States according to the apportionment formula. ${ }^{\mathbf{2 8}}$ The CCCTB proposal also includes an extensive number of detailed provisions on the administrative procedures of the different tax authorities and how the coordination between tax authorities of Member States would be realized. For the purposes of this article, these provisions do not need to be addressed in more detail.

\section{I. The Scope of the Legislation}

The scope of the CCTB and CCCTB proposals are similar. Following the rules set in directives would be mandatory to companies belonging to a consolidated group for financial accounting purposes with a total consolidated group revenue that exceeded EUR 750000000 during the financial year preceding the relevant financial year. ${ }^{29}$ The company must also qualify as a parent company or qualifying subsidiary, take one of the company forms listed in Annex $\mathbf{1}^{\mathbf{3 0}}$ of the directive, and be subject to one of the corporate taxes listed in Annex $\|^{\mathbf{3 1}}$ or to a similar tax subsequently introduced. ${ }^{32}$ The list of company forms differs from country to country, and the scope of the CCTB and CCCTB directive proposals is set with both naming out the specific company forms and, as in the case of the Netherlands and Austria, regulating that all companies subject to national corporate tax are also subject to the directive if they fulfil the rest of the criteria.

For smaller companies that do not meet the threshold or fulfil the other relevant criteria, following the CCCTB rules would not be mandatory, and they could instead select following national tax regulation. The directive outlines the ways in which corporations may opt into the CCCTB rules and opt out of them.

Making CCCTB mandatory for large companies is a significant change in the approach of the Commission in comparison to the CCCTB directive proposal of 2011. The 2011 directive proposed a fully voluntary system that companies could decide to follow or not to follow. ${ }^{\mathbf{3 3}}$

28 Van der Jagt, R., "Euro Tax flash from KPMG's EU Tax Centre" (KPMG EU Tax Center, 2016); European Commission, 'Proposal for a Council Directive on a Common Consolidated Corporate Tax Base (CCCTB)' COM (2016) 683 final, Chapter IX.

29 European Commission, 'Proposal for a Council Directive on a on a Common Corporate Tax Base (CCTB)' COM (2016) 685 final, art. 2(1).

30 In Annex I, companies under Finnish law known as osakeyhtiö/aktiebolag, osuuskunta/andelslag. säästöpankki/sparbank and vakuutusyhtiö/försäkringsbolag are listed.

31 In Annex II, yhteisöjen tulovero/inkomstskatten is listed.

32 European Commission, 'Proposal for a Council Directive on a Common Consolidated Corporate Tax Base (CCCTB)' COM (2016) 683 final, art. 2(1)

33 European Commission, 'Proposal for a Council Directive on a Common Consolidated Corporate Tax Base (CCCTB)' COM (2O11) 0121 final, art. 2 and art. 6. 
The scope of the CCCTB proposal can be subjected to criticism. One of the criticisms can be directed towards the creation of a boundary at EUR 750000000 , which could potentially limit the proposal's ability to achieve its aims, such as tackling tax evasion. The Commission argues in favour of the boundary by stating that limiting the compulsory application to groups with a consolidated turnover above EUR 750000000 serves the purpose of capturing the vast majority (64\%) of turnover generated by groups while limiting the risk of including purely domestic groups. $^{34}$

A valid argument for the boundary could also be that the legislation, being based on Article 115 TFEU and subject to principles of subsidiarity and proportionality, should limit its scope to situations which directly affect the establishment or functioning of the internal market. Creating a boundary at EUR 750000000 is one way, even if not a perfect one, to try to achieve this.

\subsection{Single Set of Rules on Calculating Taxable Profits}

Outlined in chapter II of the CCTB directive, the proposal's first aim is to create common rules on calculating the tax base. The proposal sets general principles, points out the elements of the tax base and provides rules on exempt revenues and deductible and non-deductible expenses.

The general principles provided in article 6 of CCTB directive proposal include that in calculating the tax base, profits and losses shall be recognized only when realized, transactions and taxable events shall be measured individually, the calculation of the tax base shall be carried out in a consistent manner unless exceptional circumstances justify a change and the tax base shall be calculated for each tax year unless otherwise provided. ${ }^{\mathbf{3 5}}$ The approach of the Commission is that the tax base is designed broadly and all revenues will be taxable unless expressly exempted. ${ }^{\mathbf{3 6}}$

The proposal provides specific rules on interest deductibility, controlled foreign companies, hybrid mismatches and exit taxes. These rules are meant to tackle tax avoidance. ${ }^{37}$ The set of rules also includes an allowance for growth and investment (AGI), which is designed to reduce debt bias, and tax incentives for research and development (R\&D) activities, including an enhanced super-deduction for start-ups. ${ }^{38}$ It's common for the member states' tax legislation

34 European Commission, 'Proposal for a Council Directive on a Common Consolidated Corporate Tax Base (CCCTB)' COM (2016) 683 final, Explanatory Memorandum.

35 European Commission, 'Proposal for a Council Directive on a on a Common Corporate Tax Base (CCTB)' COM (2016) 685 final, art. 6.

36 Ibid, art. 7.

37 Bhogal, S., Swanson, K., "EU CCCTB: The Potential Successes and challenges" (International Tax Review, 2016).

38 Bhogal, S., Swanson, K., "EU CCCTB: The Potential Successes and challenges" (International Tax Review, 2016). to favor debt based investments over equity based financing, which can be viewed as a negative situation that the introduction of AGI would to some extent correct.

The reason for creating a single set of rules on calculating taxable profits is to create a Common Corporate Tax Base in the internal market. This is the first part of the Commission's twostep approach.

\subsection{Consolidation}

As a term, consolidation refers to the underlining idea of combining the results of subsidiarity companies and integrating them to the result of the parent company. As an effect of consolidation, the tax bases of all members of a group of companies shall be added together into a consolidated tax base. If the consolidated tax base is negative, the loss will be carried forward and set off against the next positive consolidated tax base. ${ }^{39}$ For when the tax base is positive, the CCCTB directive contains provisions on how it will be apportioned to Member States. ${ }^{40}$

The parent company of the group needs to have a right to exercise more than $50 \%$ of the voting rights, and have an ownership right amounting to more than $75 \%$ of the subsidiary's capital or own more than $75 \%$ of the rights giving entitlement to profit, for the subsidiarity to qualify for consolidation. Specific rules apply for calculating the thresholds for lower-tier subsidiaries. ${ }^{41}$

Profits and losses arising from intra-group transactions must be consistent and adequately documented by the group and ignored when calculating the consolidated tax base. ${ }^{\mathbf{4 2}}$

\subsection{Apportionment}

One of the key elements of the CCCTB proposal is the formula for formula apportionment. ${ }^{43}$ It is worth noting that the apportionment, which might be the most publicly visible and easily comprehendible part of the Commission's two-step proposal, builds on the other notions of CCTB and CCCTB directive proposals. For formula apportionment to work, common rules on both calculating the tax base and consolidating it must be adopted and implemented by Member States. It can also be interpreted that reaching the situation of European-wide formula apportionment of corporate tax income is to some extent the end-goal of the Commission.

39 European Commission, 'Proposal for a Council Directive on a Common Consolidated Corporate Tax Base (CCCTB)' COM (2016) 683 final, art. 7.

40 Ibid, Chapter VIII.

41 Ibid, art. 5

42 lbid, art 9

43 lbid, art. 28 
As explained earlier when examining formula apportionment as the foundation of CCCTB proposal, the formulas followed may vary, and even the proposed CCCTB directive leaves an option of subsequently changing the formula with the so-called safeguard clause. ${ }^{44}$ The formula now proposed by the Commission gives equal weight to the factors of sales, labour and assets.

Share $A=\left(\frac{1}{3} \frac{\text { Sales }^{A}}{\text { Sales }^{\text {Group }}}+\frac{1}{3}\left(\frac{1}{2} \frac{\text { Payroll }^{A}}{\text { Payroll }^{\text {Group }}}+\frac{1}{2} \frac{\text { No of employees }^{A}}{\text { No of employees }^{\text {Group }}}\right)+\frac{1}{3} \frac{\text { Assets }^{A}}{\text { Assets }^{\text {Group }}}\right) \approx$ Con'd Tax Base $^{\prime}$

Graph 1. Appropriation formula of the CCCTB directive $\mathbf{4 5}^{\mathbf{5}}$

In the Commission's proposal, the consolidated tax base is first calculated. Along with this tax base, the three factors determining the apportionment are calculated according to the following rules.

\section{a) Sales factor}

The sales factor consists of the total sales allocated to a group member as its numerator and the total sales of the group as its denominator. Intra-group sales and exempt revenues, which are listed in the proposal, will not be included in the factor. ${ }^{\mathbf{4 6}}$

In composing the sales factor, the difficulty lies in how the sale of goods and services are allocated to a group member. This has a significant effect on the outcome of the formula and on the distribution of corporate tax income to different Member States. In CCCTB, the approach chosen is to attribute the sales to a group member located in the Member State where the dispatch or transport of the goods to the person acquiring them ends. If this can't be determined, last identifiable location of the goods is used. In the case of services, they shall be included in the sales factor of the group member located in the Member State where the services are physically carried out or actually supplied. ${ }^{\mathbf{4 7}}$

If there is no group member in a Member State or sales are carried out in third countries, sales factor is in effect not used. In these cases, the sales of goods and supply of services shall be included in the sales factor of all group members in proportion to their labour and asset factors. ${ }^{48}$

Composition of the sales factor can be subjected to some critical observations. With digital economy forming an ever-growing part of the economic activity in the internal market, does the proposal give enough thought on how the formula would treat these sales? Would the distribution of tax revenue produced by these sales be fair and provide Member States with the right incentives? If tax revenue produced by sales to third countries would be distributed by labour and assets factors, not by where the innovations and added value are created, would this urge the Member States to facilitate the necessary investments to R\&D, education and innovative growth?

My answer to these questions is negative, and it's safe to say that the digital economy and its growing role are not sufficiently featured in the Commission's reasoning and memorandums provided to support the directive proposal. This may result from the fact that many elements of the CCCTB proposal were already drafted in the early part of 2000's, and the development of digital economy has been rapid after that. However, in order for a reform of this size to pass, these elements should be revisited by the Commission. If for no other reason, then to effectively communicate to numerous stakeholders of the CCCTB that these developments in the internal market have been a factor of in-depth considerations by the Commission.

\section{b) Payroll factor}

Payroll factor consist of salaries, wages, bonuses and all other employee compensations and is valued at the amount of expenses that are treated as deductible by the employer in a tax year. Employees shall be included in the labour factor of the group member from which they receive remuneration. Exception to this rule is made when more at least $5 \%$ of the workforce of the salary-paying group member is working under the supervision of another group member for at least three months. ${ }^{49}$

The $5 \%$ clause hinders companies from trying to distort the formula by remunerating employees located in another Member State from a company located in a Member State with a lower statutory tax rate, therefore achieving lower effective corporate tax rate for the group consolidated tax base.

\section{c) Assets factor}

The assets factor consists of the average value of all fixed tangible assets owned, rented or leased by a group member as its numerator and the average value of all fixed tangible assets owned, rented or leased by the group as its denominator. ${ }^{\mathbf{5 0}}$ Assets are included in the asset factor of their economic owner, and if the economic owner cannot be identified, in the asset factor of the legal owner. ${ }^{51}$ Noteworthy in the calculation of assets factor is that intangible assets are excluded from the base of the asset factor. ${ }^{\mathbf{5 2}}$

52 Van der Jagt, R., "Euro Tax flash from KPMG's EU Tax Centre" (KPMG EU Tax Center, 2016). 


\section{COMMISSION ARGUMENTS FOR LEGAL BASIS AND COMPATIBILITY WITH EU PRIMARY LAW}

The Commission gives its reasoning on the legal basis, subsidiarity and proportionality on the Explanatory Memorandum of the proposals. The Explanatory Memorandum is identical in CCTB and CCCTB directive proposals.

According to the Commission, the CCTB and CCCTB proposals fall within the ambit of Article 115 TFEU, and therefore the European Union has non-exclusive competence to regulate. The Commission reasons that it is evident that in order to create a fairer and more coherent tax environment for businesses to operate, action is necessary to be taken not separately by Member States in an uncoordinated fashion, but at the level of the Union instead. ${ }^{\mathbf{5 3}}$ Below, some of the core arguments of the Commission are observed.

According to the Commissions Explanatory Memorandum, the proposed directives are compatible with the principle of subsidiarity e.g. because:

a) The objectives of CCTB and CCCTB essentially seek to tackle problems beyond a single Member State and therefore by nature require a common approach.

b) The interaction between different tax systems generates opportunities for abuse of mismatches, and since the EU is an internal market with a high degree of cross-border activity, there is a need of agreeing to coordinated solutions.

c) Most key features of the CCCTB system could only be dealt with through collective action, and separate action by Member States would only solve significant issues bilaterally in the best-case scenario.

The proposed regulation complies with the principle of proportionality e.g. because:

a) The envisaged measures are both suitable and necessary for achieving the desired end. They do not go further than harmonizing the corporate tax base, which is a prerequisite for curbing identified obstacles that distort the internal market, and do not restrict Member States' sovereignty to determine their own corporate tax rates.

b) EU level coordination alone would not be sufficient for eradicating tax-related distortions in the internal market because it's a slow process and focuses on specific issues, rather than addressing the larger variety of problems regarding corporate taxation and the internal market, which require a holistic approach.

c) The mandatory scope of CCCTB only targets groups of companies above a certain size,

53 European Commission, 'Proposal for a Council Directive on a Common Consolidated Corporate Tax Base (CCCTB)' COM (2016) 683 final, Explanatory Memorandum. which tend to possess sufficient resources which would allow them to engage in aggressive tax planning strategies under the current regulatory framework.

Weather all the claims and concerns of the Explanatory Memorandum of the proposal are proportioned to the depth of the problem and all-in-all well-reasoned, remains for individual interpretation. In my view, some of the statements are primarily meant to underline the competence of the European Union to regulate on the issue. It's an unequivocal fact that profit shifting and tax avoidance result in loss of tax revenue on the side of the Member States, but it's far from an unanimously agreed that these losses i.e. "distort price signals and the allocation of resources" like the Commission claims. It is rather hard to justify such a claim from the perspective of economic literature, and tax competition can even be viewed to have positive effects on the allocation of resources. Scientific literature has e.g. showed that tax competition results in private sector growth, higher output and higher consumption from more efficient taxation. ${ }^{\mathbf{5 4}}$

\section{REASONED OPINIONS OF THE NATIONAL PARLIAMENTS}

Seven national parliaments voiced their Reasoned Opinions in objection to the Commission's interpretation of the principle of subsidiarity regarding CCCTB and CCTB. ${ }^{\mathbf{5 5}}$ These seven parliaments come from six Member States, because both the Senate and the House of Representatives from the Netherlands submitted separate Reasoned Opinions. Therefore, the Commission does not have to revisit its proposal. ${ }^{\mathbf{5 6}}$ Even though the Reasoned Opinions are too few to force the Commission to reconsider its proposal, they are plenty to evoke the discussion of the compatibility of CCTB and CCCTB with EU Primary law.

It should also be noted that some of the parliaments submitted positive Political Opinions regarding the proposal and expressed their support for it - even though simultaneously pointing out areas of improvement. This is the case for instance with the opinions submitted by the Federal Council of Austria ${ }^{\mathbf{5 7}}$ and Parliament of the Czech Republic, ${ }^{\mathbf{5 8}}$ and to the extent of the CCTB, with the opinion of the Romanian Chamber of Deputies. ${ }^{59}$ Other parliaments, such as

54 Gordon, B., "Tax competition and harmonisation under EU law: economic realities and legal rules" (E.L. Rev. 2014, 39(6)) p. 790-811.

55 The platform for EU Interparliamentary Exchange (IPEX), Proposal for a Council Directive on a Common Corporate Tax Base COM/2016/0685; The platform for EU Interparliamentary Exchange (IPEX). Proposal for a Council Directive on a Common Consolidated Corporate Tax Base COM/2016/0683.

56 Protocol (No 2) on the application of the principles of subsidiarity and proportionality [2016] OJ C202/206, art 7 .

57 Political Dialogue Opinion of the Austrian Federal Council on COM (2016) 682, COM (2016) 683 (CCCTB) and COM (2016) 685 (CCTB).

58 Resolution of the Senate of the Parliament of the Czech Republic on COM (2016) 685, COM (2016) 683, COM (2016) 686 and COM (2016) 687.

59 Political Dialogue Opinion of the Romanian Chamber of Deputies on COM (2016)682, COM (2016) 683 (CCCTB) and COM (2016) 685 (CCTB). 
the House of Representatives of Cyprus ${ }^{\mathbf{6 0}}$ and German Bundesrat ${ }^{\mathbf{6 1}}$ did not raise subsidiarity issues but were critical towards the content of the proposal.

Out of all the National Parliaments, the approach of the Irish Houses of Oireachtas is the most critical. This is perhaps not surprising, because Ireland is widely considered to be one of the Member States fiscally benefitting from the current European corporate tax system.

One of the criticisms of the Houses of Oireachtas is that the Commission has not provided enough information about the proposal. The Houses of Oireachtas also states its reserved approach towards the calculations that have been made by the Commission on tax revenue and GDP growth. ${ }^{62}$

Regarding subsidiarity, the Houses of Oireachtas is of the opinion that the implications of the proposals fall within the area of tax policy and thus impinge on a national competency. The Houses of Oireachtas also believes that the proposals impact directly on sovereign tax rates currently in place and the ability of Member States to set tax rates in the future. In addition to this, the Houses of Oireachtas voices its objection to the proposals e.g. for inefficiency, being counterproductive towards similar OECD proposals, narrowing the tax base, undercutting Irelands ability to fund public services, losing case law and administrative expertise and on the composition of the appropriation formula. ${ }^{63}$

The House of Representatives of Malta determines that less intrusive instruments can lead to the objectives of CCTB and CCCTB without interfering with national tax autonomy. ${ }^{64}$ The House of Representatives sees a possibility that adopting the CCTB would require Member States to change their tax rates, views that the CCTB does not eliminate transfer pricing to a necessary degree, and sees previous actions by the EU, such as the Directive laying down rules against tax avoidance practices that directly affect the functioning of the internal market

60 Political Dialogue Opinion of the House of Representatives of the Republic of Cyprus on the Commission proposals for a Common Corporate Tax base - COM (2016)0685 (CCTB) and COM (2016)0683 (CCCTB) - executive summary in English.

61 Beschluss des Bundesrates, Vorschlag für eine Richtlinie des Rates über eine Gemeinsame Körperschaftsteuer-Bemessungsgrundlage COM(2016) 685 final; Ratsdok. 13730/16.

62 Reasoned opinion of the Irish Houses of Oireachtas on the Commission proposals for a Common Corporate Tax base - COM (2016)0685 (CCTB) and Common Consolidated Corporate Tax Base COM (2016)0683 (CCCTB)

63 Reasoned opinion of the Irish Houses of Oireachtas on the Commission proposals for a Common Corporate Tax base - COM (2016)0685 (CCTB) and Common Consolidated Corporate Tax Base COM (2016)0683 (CCCTB).

64 Reasoned opinion of the House of Representatives of Malta on the Commission proposals for a Common Corporate Tax base - COM (2016) 0685 (CCTB); Reasoned opinion of the House of Representatives of Malta on the Commission proposals for a Common Consolidated Corporate Tax base - COM (2016) 0683 (CCCTB). $\left(\right.$ ATAD I ${ }^{65}$ and directive regarding hybrid mismatches with third countries (ATAD II), ${ }^{66}$ to be enough to counter unintended opportunities of tax avoidance.

In its Reasoned Opinion on CCCTB, the House of Representatives criticizes the added administrative burden companies following CCCTB would have to face, since even though the group as whole would only have to interact with one tax authority, individual companies in the group would have to provide extensive information to the principal tax contributor. This would add administrative burden within the group, even if the interaction with authorities would become easier. ${ }^{67}$

One element of concern for the House of Representatives is also the effect CCCTB and the apportionment formula would have on the Maltese economy and tax revenue. The House considers the formula to penalize economies with high productivity level and/or where the market size is limited and result in creating comparative advantages to Member States with economies dependent on labour-intensive economic sectors. The criticism of the House of Representatives is somewhat well founded from the perspective of the formula benefitting labour-intensive economies and penalizing smaller economies with high productivity. This is especially true with sales to third countries. ${ }^{68}$

Swedish ${ }^{\mathbf{6 9}}$ and Danish Parliaments ${ }^{\mathbf{7 0}}$ raised similar concerns than the Irish Houses of Oireachtas on the Commission not providing sufficiently clear information on both proposals separately for it to be possible to conduct evaluation of necessary quality on their compliance with the principles of subsidiarity and proportionality.

Dutch Senate criticizes the proposals for not providing a minimum rate of corporate tax. ${ }^{71}$ This is somewhat paradoxical, since the interpretation of the Senate is that even the current CCTB and CCCTB proposals are not compliant with the principle of subsidiarity, and a common minimum tax rate should in this regard undoubtedly be considered more far-reaching than the current proposals.

65 Council Directive (EU) 2016/1164 of 12 July 2016 laying down rules against tax avoidance practices that directly affect the functioning of the internal market [2016] OJ L193/1.

66 Council Directive (EU) 2017/952 of 29 May 2017 amending Directive (EU) 2016/1164 as regards hybrid mismatches with third countries.

67 Reasoned opinion of the House of Representatives of Malta on the Commission proposals for a Common Consolidated Corporate Tax base - COM (2016) 0683 (CCCTB).

68 See section 2.4.1. Sales factor

69 Reasoned opinion of the Parliament of Sweden on the Commission proposals for a Common Corporate Tax base - COM (2016) 0685 (CCTB); Reasoned opinion of the Parliament of Sweden on the Commission proposals for a Common Consolidated Corporate Tax base - COM (2016) 0683 (CCCTB).

70 Reasoned opinion of the Parliament of Denmark on the Commission proposals for a Common Corporate Tax base - COM (2016) 0685 (CCTB) and Common Consolidated Corporate Tax Base - COM (2016) 0683 (CCCTB) - courtesy translation

71 Reasoned opinion from the Senate of the Kingdom of the Netherlands on COM (2016) 683, COM (2016) 685 and COM (2016) 687 - courtesy translation. 
Luxembourg Chamber of Deputies shares many of the same concerns of other National Parliaments that submitted reasoned opinions. ${ }^{\mathbf{7 2}}$

The Reasoned Opinions submitted by seven national parliaments leave a lot to be desired. Many of them offer little to no analysis on the proposals and do not engage in an in-depth discussion on the actual substance of principles of subsidiarity and proportionality. Instead of monitoring the proposal from the perspective of fundamental principles of EU law, the national parliaments have mainly based their arguments on the political and technical aspects of the proposed directives. Reasoned Opinions take the form of political dialogue, raising political and technical arguments instead of legal ones.

However, the Reasoned Opinions give clear indications of the concerns circulated in various Member States, and all-in-all shed light to a very critical and hesitant response by Member States towards the proposal. It should also be noted that silence by a national parliament does not necessarily translate to approval. This is the case at least with Finland, where the Grand Committee of the Parliament adopted critical statements of the proposal in late 2016, but did not submit a Reasoned Opinion. ${ }^{\mathbf{7 3}}$ The Finnish Parliament has previously held that submitting Reasoned Opinions is not an effective way of affecting EU legislation. ${ }^{\mathbf{7 4}}$ In the light of this, it would be unlikely that the Finnish Government would support the CCCTB initiative in its current form. This may be the case also with other parliaments and governments.

\section{CHALLENGES OF THE CCCTB}

When analyzing the responses of national parliaments towards the CCСTB and CCTB, it becomes clear that the proposals have a rocky path ahead of them. Many of the more significant challenges are political.

\section{I. Political Challenges}

One obvious fact is that the Member States are reluctant to hand out significant new powers to the European Union. Taxation has traditionally been considered one of the fundamental elements of a Nation State. It is to a large extent understandable that national parliaments and governments take a hesitant stance towards regulating direct taxation on the EU level.

72 Reasoned opinion of the Luxembourg Chamber of Deputies on the Common Corporate Tax base COM (2016) 0685 (CCTB); Reasoned opinion of the Luxembourg Chamber of Deputies on the Common Consolidated Corporate Tax Base - COM (2016) 0683 (CCCTB).

73 Suuren valiokunnan lausunto, "Valtioneuvoston kirjelmä eduskunnalle ehdotuksesta neuvoston direktiiviksi yhteisestä yhteisöveropohjasta (CCTB)" (SuVL 8/2016 vp); Suuren valiokunnan lausunto, "Valtioneuvoston kirjelmä eduskunnalle ehdotuksesta neuvoston direktiiviksi yhteisestä yhdistetystä yhteisöveropohjasta (CCCTB)" (SuVL 9/2016 vp).

74 Suuren valiokunnan mietintö, "Valtioneuvoston selonteko EU-politiikasta 2013" (SuVM 1/2014 vp).
However, the political challenges of the CCCTB go far beyond the division of powers between the Member States and the European legislature. It is also the previous difficulties in the field of taxation that explain the skepticism of the Member States. So far, a relatively small sub-set of the member states has been able to agree on the terms of a Financial Transaction Tax, which is immensely more straightforward than the CCCTB. ${ }^{\mathbf{7 5}}$ In the light of this, the CCCTB may look like an unrealistic endeavor to many Member States.

In the minds of the Member States may also lie the failure of creating a common and consolidated VAT regime, which has been in process since the 1980's. The Commission's aim was originally to create a common and consolidated VAT regime which would allocate VAT revenues to the Member states through a central account - a vision very similar to the CCCTB. Clear analogy between the VAT proposal and the CCTB and CCCTB can be found also in the Commission's twostep approach, which in the case of VAT ended up creating a de facto permanent "transitional" VAT regime when the latter parts of the proposal failed to attract the necessary support. ${ }^{\mathbf{7 6}}$ This may well evoke expectations of similar results with the CCTB and CCCTB. The question then lies if achieving the CCTB is better than achieving nothing at all, since achieving the CCCTB could prove to be impossible. Many Member States may then find themselves reluctant to engage in the project if they view the CСTB to be inefficient as a stand-alone solution, which is also to some extent the view of the Commission.

Another political hurdle on the path of the CCCTB is Brexit. The Brexit negotiation period overlaps with the two-year window of the CCCTB Proposal. The United Kingdom has been one of the primary opponents of harmonizing corporate taxation and it is yet unclear what position the country will take in relation to the proposals if some parts of the harmonization could be agreed before the departure of the UK. ${ }^{\mathbf{7 7}}$

\subsection{Technical Challenges}

In addition, it should also be noted that it is not only politics blocking the path of the CCCTB. According to Primary law, tax harmonization can be executed through directives only, not regulations. When dealing with tax issues this poses a challenge. The general nature of the proposed CCCTB directive, and the fact that it leaves implementation to the Member States, might result in inconsistent implementation in different jurisdictions. This has been the case also with the common VAT regime. ${ }^{\mathbf{7 8}}$ With the CCCTB, a potential problem could lie in the areas

75 Bhogal, S., Swanson, K., "EU CCCTB: The Potential Successes and challenges" (International Tax Review, 2016).

76 Bhogal, S., Swanson, K. "EU CCCTB: The Potential Successes and challenges." (International Tax Review, 2016).

77 Bhogal, S., Swanson, K. "EU CCCTB: The Potential Successes and challenges." (International Tax Review, 2016) 
where the proposal specifically defers to domestic law. ${ }^{\mathbf{7 9}}$ In other words, the aspects that will not be harmonized could continue to create distortions.

Another concern is that formula apportionment invites for new forms of tax planning. According to de Wilde, the CCCTB would only create an easy-to-manipulate EU company tax system to which Member States would have little in the way of responding to other than by reducing their tax rates. ${ }^{80} \mathrm{~A}$ large amount of criticism is also directed towards the chosen formula components, which are viewed by some as outdated in the era of innovation-led digital economy. ${ }^{\mathbf{8 1}}$ Buttner, Riedel and Runkel argue that profit-shifting activities of multi-jurisdictional enterprises are in fact maintained under a tax system of consolidation and formula apportionment, although the activities themselves may differ from the ones now seen in the internal market. ${ }^{\mathbf{2}}$

Technical and procedural questions are also raised on whether this type of EU level approach towards tax evasion is needed at all, or should the European countries be more concerned about finding a common solution in the OECD framework, and about the relation of CCCTB and international tax treaties.

\subsection{Challenges Regarding the Legal Basis}

In addition to the technical and political questions, many scholars have approached the topic from a broader perspective of the EU competences. According to Pinto, EU interference in the field of direct taxation is only allowed for tax measures directly affecting the establishment and functioning of the internal market, and in situations where the negative consequences to the internal market cannot be removed by the Member States due to their magnitude or effects. ${ }^{\mathbf{8 3}}$

Gordon compares the legal foundations for tax competition and tax harmonisation and reaches a conclusion that jurisdictional tax competition has a fundamental legal founding in the objectives of the Treaty. According to Gordon, tax competition is an economic imperative recognized and protected under EU law. ${ }^{\mathbf{8 4}}$ Gordon argues that the differences in tax systems are in fact a positive situation, because it creates an imperative for the Member States to tax more efficiently both in terms of nominal rates and tax administration. ${ }^{\mathbf{8 5}}$

79 lbid.

80 Wilde, M. "The CCCTB Relaunch: A Critical Assessment and Some Suggestions for Modification" (Erasmus University Rotterdam, 2017b)

81 lbid.

82 Buettner, T., Riedel, N., Runkel, R. "Strategic Consolidation under Formula Apportionment" (Otto Von Guericke Univeristät Megdeburg, 2008)

83 Pinto, C. "Tax competition and EU law." (The Hague; New York (N.Y.): Kluwer Law International, 2003), p. 58.

84 Gordon, B. "Tax competition and harmonisation under EU law: economic realities and legal rules" (E.L. Rev. 2014, 39(6)) p. 790-811.

85 European Commission, "Proposal for a Council Directive on a Common Consolidated Corporate Tax Base (CCCTB)" COM (2011) 0121 final.
Terra and Wattel consider relative differences in direct tax level between Member States not to be any different from factors such as economic opportunity, skilled labour force, distribution infrastructure, consumer purchasing power, political stability or climate. ${ }^{\mathbf{8 6}}$ There are disparities between Member States in these areas, so from the perspective of the internal market, there can be disparities also with tax systems and levels.

However, it should be noted that tax competition can take many forms. Member States can compete by reducing tax rates, which is something the CCCTB doesn't even try to eliminate. Member States, in the current situation, can also compete by giving specific companies tax breaks or providing other tax incentives, which can be viewed as distortions in the functioning of the internal market. The CCCTB aims to reduce these. Therefore the aim is not to eliminate tax competition completely but rather to increase its transparency and limit it to the nominal levels of corporate taxation. From this point of view, the CCCTB is not in conflict with EU Primary law.

There are multiple convincing arguments, such as the ones put forward by the Commission in its Working Paper and Explanatory Memorandum examined above, that lay out the legal basis for CCCTB Proposal and other legislative acts to harmonize direct taxations in the internal market. However, the views of legal and economic scholars also highlight that it is rather hard to argue that the current system of taxation would significantly endanger the functioning of the internal market - or that the proposed CCCTB would undoubtedly better it.

In the light of this, the Commission's reasoning and Explanatory Memorandum must be subjected to some criticism. In arguing for the benefits of EU level tax legislation, the Commission should first build a comprehensive case for the legislation from the point of view of the internal market. The spearhead of all arguments should be to identify the malfunction in the internal market, and then present a solution to this malfunction. Now, it seems, the Commission is more focused on linking the proposal to its own aims of fair taxation than to the legal basis on which it operates.

\subsection{Competence to Engage in Bilateral or Individual Measures}

In addition to EU legislative competence, the competencies of the Member States should also be observed. To what extent, when considering the EU law framework, can Member States engage in individual and bilateral initiatives to fight tax evasion? When are these measures considered to be limitations to the exercise of Treaty freedoms?

The ECJ has held that exercising Treaty freedoms in the purpose of benefitting from disparities in the Member State's tax legislation is an activity protected under EU law. It has on multiple occasions also confirmed the Member State's sovereignty in tax matters.

86 Terra B., Wattel, P. “European Tax Law”, 6th edn (The Hague: Wolters Kluwer, 2012), p.222. 
Many of the cases brought to the Court have been related to the treatment of non-resident companies in Member States and resulted in laying out the scope of tax jurisdiction of individual Member States in these individual cases. In one of its landmark rulings on direct taxation, the Court held that it is the competence of the contracting parties to define the criteria regarding double taxation and allocation of tax jurisdiction between the parties. ${ }^{\mathbf{8 7}}$

The Court has held that "according to the settled case law, although direct taxation falls within their competence, the Member States must none the less exercise that competence consistently with EU law and avoid any discrimination on grounds of nationality." 88 This illustrates the underlying approach of the ECJ towards taxation: the allocation of taxation powers is not reviewable by the Court, but the exercise of allocated tax jurisdiction is. ${ }^{89}$ Therefore, the allocation would fall outside the competence of the Treaties, and no discussion of competences of the Member States would be relevant.

Regarding the exercise of taxation powers, the Court has viewed that many, sometimes even clear, restrictions have filled the requirement of being "objectively justified by an overriding reason in the public interest." ${ }^{\text {"90 }}$ This requirement needs to be fulfilled for a restriction to be compliant with EU law. What is notable, however, is that tax revenue loss for the Member State has never been accepted as a justification. On the other hand, it seems that combatting tax avoidance and the effectiveness of fiscal supervision are accepted as valid arguments by the Court. ${ }^{91}$

Whether a specific restriction to Treaty freedoms is compliant with EU law is in the end a question left to the Court and needs to be examined on an individual basis. No overarching rule can be drawn from the ECJ case law. In general terms it can be stated that as long as the provisions or administrative procedures are not discriminatory or pose unjustified restrictions to the exercise of Treaty freedoms, the Member States have a fairly unrestricted and broad playing-field when engaging in bilateral tax agreements with other Member States and third countries or bringing forward legislative acts. This analysis is relevant especially when considering alternatives to the CCCTB, if the proposal fails to reach unanimity in the Council. It seems that the Primary law allows for both enhanced cooperation regarding the CCCTB and multi- and bilateral agreements between Member States.

87 Case C-336/96 Mr and Mrs Robert Gillyv. Directeur des Services Fiscaux du Bas-Rhin EU:C:1998:826 88 Case C-170/05 Société Denkavit International BV and Denkavit France Sarl v. Minstre l'Économie des Finances et de l'Industrie EU:C:2006:11949, para. 19.

89 Mitroyanni, I. "Integration approaches to group taxation in the European internal market" (Alphen aan den Rijn, The Netherlands: Kluwer Law International, 2008), p. 6.

90 lbid, p. 11 .

91 Ibid, p. 11 .

\section{POSSIBLE SOLUTIONS}

Based on the previous examinations of the CСCTB Proposal, the responses by National Parliaments, and criticisms the proposal has received, it is relatively safe to say that the proposal has a difficult path ahead of it. Below, some of the other solutions to the conflict between national tax autonomy and the internal market are examined.

\section{I. Enhanced Cooperation}

If achieving the CCCTB in the whole internal market would prove impossible, the obvious next steps for willing Member States would be to continue with the proposals by enhanced cooperation. With the procedure of enhanced cooperation, minimum of $9 \mathrm{EU}$ countries are allowed to establish advanced integration or cooperation in an area within EU structures but without the other EU countries being involved..$^{\mathbf{9 2}}$

The situation would be analogous to the 'financial transaction tax' (FTT), based on Article 113 TFEU, which failed to receive unanimous support in the Council. After that, 11 Member States decided to pursue with enhanced cooperation in the matter, which was authorized by the Council in 2013. The United Kingdom challenged the Council's decision in the Court of Justice, which upheld the decision. ${ }^{93}$ The Court's decision, along with other recent case law, illustrates that it is difficult for non-participating Member States to prove that enhanced cooperation endangers their interests or the interests of the Internal Market more generally. ${ }^{\mathbf{9 4}}$ Whether enhanced cooperation in the form of CCCTB would be upheld in the Court would require a more in-depth analysis.

Even if the applicability of enhanced cooperation to the CCCTB would require more analysis, it should not be neglected as an option if the CCCTB fails to reach unanimity in the Council. It was also the view of the Rapporteur of the European Parliament that, if unanimity is not found, the Council should without delay initiate the procedure for a decision authorizing enhanced cooperation in the area of the CCCTB. ${ }^{95}$

92 Council Decision 2013/52/EU of 22 January 2013 authorising enhanced cooperation in the area of financial transaction tax

93 Case C-209/13, United Kingdom of Great Britain and Northern Ireland v. Council of the European Union [2014].

94 Anzhela, C. "Enhanced cooperation: A way forward for tax harmonization in the EU?" (Oxford University Centre for Business Taxation Working paper series WP 15/33, 2015), p. 40

95 European Parliament Draft Report on the proposal for a Council directive on a Common Consolidated Corporate Tax Base (CCCTB) (COM(2016)0683 - C8-0471/2016 - 2016/0336(CNS)), European Parliament legislative resolution of $15 \mathrm{March} 2018$ on the proposal for a Council directive on Common Consolidated Corporate Tax Base (CCCTB) (COM(2016)0683 - C8-0471/2016 - 2016/O336(CNS)). 
Dettendorf, van der Horts, de Mooij and Vrijburd find that a coalition of similar countries, in terms of the size of their multinational sector, is more feasible in achieving agreement and is preferred by those countries over a Europe-wide reform. ${ }^{96}$ For individual countries, the benefits from consolidation and formula apportionment are diverse and depend on the formula of choice. Therefore, enhanced cooperation, according to at least some literature, might not be an inferior solution in comparison to the CCCTB encompassing the entire internal market. On the other hand, it is clear that this approach would not create an entirely level playing field in the internal market, which is one of the aims of the Commission.

\subsection{Article 116 TFEU}

According to a resolution adopted with a large majority by the European Parliament, if the Council fails to adopt a unanimous decision on the proposal to establish a CCCTB, the Commission should issue a new proposal based on Article 116 of the TFEU. ${ }^{97}$ The Article 116 TFEU reads, that where the Commission finds that a difference between the provisions laid down by law, regulation or administrative action in Member States is distorting the conditions of competition in the internal market and that the resultant distortion needs to be eliminated, the European Parliament and the Council, acting in accordance with the ordinary legislative procedure, shall issue the necessary directives. Any other appropriate measures provided for in the Treaties may be adopted, and before issuing directives, consultations need to be conducted with the Member States.

The stance of the European Parliament is that the Commission should act on the legal basis of Article 116 TFEU and enhanced cooperation is only the last resort. ${ }^{\mathbf{9 8}}$ This view is somewhat radical because the use of Article 116 would undoubtedly receive hard criticism from many Member States.

The big difference between Article 115 and 116 is that when issuing a proposal on the legal basis of the latter, instead of unanimity in the Council, majority in the European Parliament and qualified majority in the Council is required. When considering the strong support for the CCCTB in the Parliament, this approach would make it far more likely that the CCCTB would pass the scrutiny of the European legislature.

The major problem with this approach is that it is unclear whether the ECJ would consider the legal basis as valid.

96 Bettendorf, L., van der Horsty, A., de Mooijz, R., Vrijburg H. "Corporate Tax Consolidation and Enhanced Cooperation in the European Union" (European Tax Policy Forum, 2009).

97 European Parliament legislative resolution of 15 March 2018 on the proposal for a Council directive on a Common Consolidated Corporate Tax Base (CCCTB) (COM(2016)0683 - C8-0471/2016 2016/0336(CNS)).

98 European Parliament legislative resolution of 15 March 2018 on the proposal for a Council directive on a Common Consolidated Corporate Tax Base (CCCTB) (COM(2016)0683 - C8-0471/2016 2016/O336(CNS)).

\section{CONCLUSIONS}

This article set out to examine whether the CCCTB and CCTB proposals could prove to be a successful answer to the conflict between the internal market and national tax autonomy. The answer is dull: they could be but it is possible that they will not be.

The conflict between the internal market and national tax autonomy can in short be described as a problem of incompatibilities in national tax systems, which the European legislature is unable to address both due to the lack of legislative powers and the complexity of the problem. The positive element of the CCCTB Proposal is that it would effectively move these necessary powers to the European level and enable the Commission to continue regulating corporate taxation with the safeguard clause and other means through which the notions of the directives could be further clarified. Even if the CCCTB system would not be perfect at first, updating the regulatory framework could be more feasible after its adoption.

When noting the negative response to the initiative from numerous Member States and the technical concerns associated with the proposal, it seems likely that the CCCTB will not pass the scrutiny of the Council. The question then lies on how we understand the CCCTB. If we strictly focus on the current proposal and its notions, then the analysis of its capabilities to solve the conflict between tax autonomy and internal market seem dim. However, if we look at the CCCTB as a system of formula apportionment and as an evolving framework which can be enacted in parts of the internal market through enhanced cooperation - or agree with the European Parliament which believes the Commission should use the legal basis of Article 116 TFEU - the outcast looks more positive.

The CCCTB is perhaps not perfect, but it might very well be the best we can come up with in terms of harmonizing corporate taxation in the internal market, while allowing the Member States to maintain their autonomy in setting the rates for corporate taxation. 


\section{TABLE OF LEGISLATION}

\section{EU Primary Law}

Consolidated Version of the Treaty on European Union [2016] OJ C202/13

Consolidated Version of the Treaty on the Functioning of the European Union [2016] OJ C202/47

EU Secondary Law and Secondary Law Proposals

European Commission, 'Proposal for a Council Directive on a Common Consolidated Corporate Tax Base (CCCTB)' COM (2016) 683 final

European Commission, 'Proposal for a Council Directive on a Common Consolidated Corporate Tax Base (CCCTB)' COM (2011) 0121 final

European Commission, 'Proposal for a Council Directive on a on a Common Corporate Tax Base (CCTB)' COM (2016) 685 final

Council Directive (EU) 2016/1164 of 12 July 2016 laying down rules against tax avoidance practices that directly affect the functioning of the internal market [2016] OJ L193/1

Council Decision 2013/52/EU of 22 January 2013 authorizing enhanced cooperation in the area of financial transaction tax

Council Directive (EU) 2017/952 of 29 May 2017 amending Directive (EU) 2016/1164 as regards hybrid mismatches with third countries

Protocol (No 2) on the application of the principles of subsidiarity and proportionality [2016] OJ C2O2/206

Regulation EC No 1606/2002 of the European Parliament and of the Council of 19 July 2002 on the application on international accounting standards [2002] L243/1

\section{BIBLIOGRAPHY}

\section{Cases of the European Court of Justice}

Case C-336/96 Mr and Mrs Robert Gilly v. Directeur des Services Fiscaux du Bas-Rhin EU:C:1998:826

Case C-170/05 Société Denkavit International BV and Denkavit France Sarl v. Minstre l'Économie des Finances et de l'Industrie EU:C:2006:11949,

\section{Official documents}

Beschluss des Bundesrates, Vorschlag für eine Richtlinie des Rates über eine Gemeinsame Körperschaftsteuer-Bemessungsgrundlage COM(2016) 685 final; Ratsdok. 13730/16
Communication from the European Commission to the European Parliament and the Council, "Anti-Tax Avoidance Package: Next steps towards delivering effective taxation and greater tax transparency in the EU", (COM 23 final, 2016) <http://eur-lex.europa.eu/legal-content/EN/ TXT/?uri=COM:2016:23:FIN> accessed on 29th of March 2018

European Commission Press release, "Commission proposes major corporate tax reform for the EU”, (IP/16/3471, 2016) <http://europa.eu/rapid/press-release_IP-16-3471_en.htm> accessed on 15th of March 2018

European Commission, "Commission Staff Working Document: Corporate Income Taxation in the European Union", (COM 302 final, 2015) <https://ec.europa.eu/taxation_customs/sites/ taxation/files/docs/body/swd_2015_121.pdf > accessed on 15th of March 2018

European Council presidency compromise text on the Proposal on a Common Consolidated Corporate Tax Base (CCCTB), (15756/14, 2014) <http://data.consilium.europa.eu/doc/document/ ST-15756-2014-INIT/en/pdf> accessed on 14th of March 2018

European Parliament Draft Report on the proposal for a Council directive on a Common Consolidated Corporate Tax Base (CCCTB) (COM(2016)0683 - C8-0471/2016 2016/0336(CNS))

European Parliament legislative resolution of 15 March 2018 on the proposal for a Council directive on a Common Consolidated Corporate Tax Base (CCCTB) (COM(2016)0683 - C80471/2016 - 2016/0336(CNS)) (Special legislative procedure - consultation)

European Parliamentary Research Service Briefing, "Common consolidated corporate tax base (CCCTB)", (PE 599.395, 2017), <http://www.europarl.europa.eu/RegData/etudes/ BRIE/2017/599395/EPRS_BRI(2017)599395_EN.pdf> accessed on 14th of March 2018

European Parliamentary Research Service Compendium of briefings, "Public opinion and EU policies - Exploring the expectations gap", (PE 586.596, 2016), <http://www.europarl.europa. eu/RegData/etudes/BRIE/2016/586596/EPRS_BRI\%282016\%29586596_EN.pdf> accessed on 15th of March 2018

Political Dialogue Opinion of the Austrian Federal Council on COM (2016) 682, COM (2016) 683 (CCCTB) and COM (2016) 685 (CCTB)

Political Dialogue Opinion of the House of Representatives of the Republic of Cyprus on the Commission proposals for a Common Corporate Tax base - COM (2016)0685 (CCTB) and COM (2016)0683 (CCCTB) - executive summary in English

Political Dialogue Opinion of the Romanian Chamber of Deputies on COM (2016) 682, COM (2016) 683 (CCCTB) and COM (2016) 685 (CCTB) 
President of the European Commission Jean-Claude Juncker, "Mission letter to European Commissioner for Competition", (2014) <https://ec.europa.eu/commission/sites/cwt/files/ commissioner_mission_letters/vestager_en.pdf> accessed on 15th of March 2018

Suuren valiokunnan lausunto, "Valtioneuvoston kirjelmä eduskunnalle ehdotuksesta neuvoston direktiiviksi yhteisestä yhteisöveropohjasta (CCTB)" (SuVL 8/2016 vp)

Suuren valiokunnan lausunto, "Valtioneuvoston kirjelmä eduskunnalle ehdotuksesta neuvoston direktiiviksi yhteisestä yhdistetystä yhteisöveropohjasta (CCCTB)" (SuVL 9/2016 vp)

Suuren valiokunnan mietintö, "Valtioneuvoston selonteko EU-politiikasta 2013" (SuVM 1/2014 vp)

Reasoned opinion of the Parliament of Denmark on the Commission proposals for a Common Corporate Tax base - COM (2016) 0685 (CCTB) and Common Consolidated Corporate Tax Base - COM (2016) 0683 (CCCTB) - courtesy translation

Reasoned opinion of the Irish Houses of Oireachtas on the Commission proposals for a Common Corporate Tax base - COM (2016)0685 (CCTB) and Common Consolidated Corporate Tax Base - COM (2016)0683 (CCCTB)

Reasoned opinion of the House of Representatives of Malta on the Commission proposals for a Common Corporate Tax base - COM (2016) 0685 (CCTB)

Reasoned opinion of the House of Representatives of Malta on the Commission proposals for a Common Consolidated Corporate Tax base - COM (2016) 0683 (CCCTB)

Reasoned opinion of the Parliament of Sweden on the Commission proposals for a Common Corporate Tax base - COM (2016) 0685 (CCTB)

Reasoned opinion of the Parliament of Sweden on the Commission proposals for a Common Consolidated Corporate Tax base - COM (2016) 0683 (CCCTB)

Reasoned opinion from the Senate of the Kingdom of the Netherlands on COM (2016) 683, COM (2016) 685 and COM (2016) 687 - courtesy translation

Reasoned opinion of the House of Representatives of the Netherlands on the Commission proposals for a Common Corporate Tax base - COM (2016)0685 (CCTB) and Common Consolidated Corporate Tax Base - COM (2016)0683 (CCCTB)

Reasoned opinion of the Luxembourg Chamber of Deputies on the Common Corporate Tax base - COM (2016) 0685 (CCTB)

Reasoned opinion of the Luxembourg Chamber of Deputies on the Common Consolidated Corporate Tax Base - COM (2016) 0683 (CCCTB)

Resolution of the Senate of the Parliament of the Czech Republic on COM (2016) 685, COM (2016) 683, COM (2016) 686 and COM (2016) 687

\section{Books}

Dahlberg, M., Direct taxation in relation to the freedom of establishment and the free movement of capital (The Hague: Kluwer Law International, 2005)

Mitroyanni, I., Integration approaches to group taxation in the European internal market (Alphen aan den Rijn, The Netherlands: Kluwer Law International, 2008)

Pinto, C., Tax competition and EU law. (The Hague; New York (N.Y.): Kluwer Law International, 2003)

Terra B. and Wattel P., European Tax Law, 6th edn (The Hague: Wolters Kluwer, 2012)

Weber, D., Tax Avoidance and the EC Treaty Freedoms (The Hague: Wolters Kluwer, 2005)

\section{Articles}

Anzhela, C. "Enhanced cooperation: A way forward for tax harmonization in the EU?" (Oxford University Centre for Business Taxation Working paper series WP 15/33, 2015) < https://www.sbs. ox.ac.uk/sites/default/files/Business_Taxation/Docs/Publications/Working_Papers/Series_15/ WP1533b.pdf> accessed 25th of April 2018

Bettendorf, L., van der Horsty, A., de Mooijz, R., Vrijburg H., "Corporate Tax Consolidation and Enhanced Cooperation in the European Union" (European Tax Policy Forum, 2009) <http:// www.etpf.org/papers/43CTCEU.pdf> accessed 25th of April 2018

Bhogal, S., Swanson, K. "EU CCCTB: The Potential Successes and challenges" (International Tax Review, 2016)

Buettner, T., Riedel, N., Runkel, R. “Strategic Consolidation under Formula Apportionment" (Otto Von Guericke Univeristät Megdeburg, 2008) <http://www.vwl1.ovgu.de/vwl1_media/downloads/ paper/Strategic+Consolidation+under+Formula+Apportionment.pdf> accessed 24th of April 2018

de Wilde, M. "Tax Competition Within the European Union Revisited - Is the Relaunched CCCTB a Solution?” (Erasmus University Rotterdam, 2017a)

de Wilde, M. "The CCCTB Relaunch: A Critical Assessment and Some Suggestions for Modification" (Erasmus University Rotterdam, 2017b)

Gerard, M., Weiner, J. M., “Cross-Border Loss Offset and Formulary Apportionment: How Do They Affect Multijurisdictional Firm Investment Spending and Interjurisdictional Tax Competition?" (CESifo. Working Paper No. 1004, 2003)

Gordon, B. "Tax competition and harmonisation under EU law: economic realities and legal rules" (E.L. Rev. 2014, 39(6)) p. 790-811 
Gutmann, D., Raingeard de la Blétière, E. "CC(C)TB and International Taxation" (EC Tax Review, 26.5.2017) p. 233-245

Jensen, P. "The EU's New Anti-Tax-Avoidance Package" (Journal of International Taxation, 27.10.2016), p. 49-54.

Krchnivá, K. "The CCCTB Allocation Formula Game: The Performance of Economics Sectors" (Prague Economic Papers, 2018)

<https://www.uclouvain.be/cps/ucl/doc/iag/documents/WP_97_Gerard.pdf> accessed 28th of March 2018

Scharpf, F.W., "The joint decision trap: lessons from German federalism and European integration" (Public administration, Volume 66, Issue 3, 1988)

Van der Jagt, R. “Euro Tax flash from KPMG's EU Tax Centre” (KPMG EU Tax Center, 2016) <https://home.kpmg.com/xx/en/home/insights/2016/10/etf-303-ccctb-proposal-published. html > accessed on 4th of April 2018 